\title{
IDENTIFIKASI PARASETAMOL DALAM JAMU PEGAL LINU YANG DIPEROLEH DARI DEPOT JAMU DI KOTA DENPASAR
}

\author{
Ni Made Maharianingsih ${ }^{1}$ \\ ${ }^{1}$ Universitas Bali Internasional \\ Email Korespondensi : maharianingsih@iikmpbali.ac.id
}

\begin{abstract}
ABSTRAK
Penggunaan obat tradisional berupa jamu sangat diminati oleh masyarakat Indonesia salah satunya berupa jamu pegal linu. Berdasarkan PERMENKES No.006/Menkes/Per/V/2012 pasal 33 dan 37 menyatakan bahwa obat tradisional tidak boleh mengandung Bahan Kimia Obat (BKO). BKO yang sering ditambahkan pada jamu pegal linu adalah parasetamol. Penelitian ini bertujuan untuk mengetahui adanya kandungan parasetamol pada jamu pegal linu yang beredar di depot jamu di kota Denpasar. Metode penelitian mengunakan metode deskriptif eksploratif dan sampel jamu diambil secara purposive sampling sebanyak 14 (empat belas) sampel jamu pegal linu sediaan serbuk berbagai merk yang dijual di depot jamu di Kota Denpasar. Penelitian dilakukan di laboratorium kimia Universitas Bali Internasional bulan Juli 2021. Sampel jamu setelah dipreparasi dilakukan identifikasi dengan kromatografi lapis tipis (KLT) dengan pemilihan fase gerak etanol p.a, deteksi dengan sinar UV $254 \mathrm{~nm}$ dan penyemprot $\mathrm{H}_{2} \mathrm{SO}_{4}$ 0,05 M. Dilakukan pula identifikasi kelengkapan penandaan produk jamu yang teridentifikasi mengandung parasetamol secara deskriptif. Sampel positif mengandung parasetamol bila didapatkan nilai $R f$ dan warna spot serupa dengan baku pembanding parasetamol. Hasil penelitian didapatkan nilai Rf sampel kode F, I, K, dan $\mathrm{L}$ adalah sebesar 0,$68 ; 0,68 ; 0,68$ dan 0,68 yang mirip dengan $\mathrm{Rf}$ baku pembanding parasetamol dan kontrol positif yaitu 0,69 serta dari 14 sampel terdapat 7 sampel yang mencantumkan nomor ijin edar fiktif. Simpulan dari penelitian adalah terdapat jamu pegal linu sediaan serbuk berbagai merk yang dijual di diduga mengandung bahan kimia obat parasetamol sebanyak 4 merk.
\end{abstract}

Kata kunci: Identifikasi, Parasetamol, Jamu pegal linu 


\title{
IDENTIFICATION OF PARACETAMOL IN JAMU PEGAL LINU OBTAINED FROM THE JAMU DEPOT IN DENPASAR CITY
}

\begin{abstract}
The use of traditional medicine in the form of herbal medicine is in great demand by the people of Indonesia, one of that is pegal linu herb. Based on PERMENKES No. 006/Menkes/Per/V/2012 articles 33 and 37 states that traditional medicine may not contain medicinal chemical. Medicinal chemical that is often added into herbal medicine for pegal linu herb is paracetamol.This study aims to determine the presence of paracetamol in pegal linu herb depots in Denpasar city. The research method used an exploratory descriptive method and samples of herbal medicine were taken by purposive sampling, 14 samples of herbal medicine of various brands that was sold at depots in Denpasar City. The research was conducted at the chemical laboratory of Bali International University in July 2021. After preparation, the fourteen samples of herbal medicine were identified using Thin Layer Chromatography (TLC) with selection mobile phase ethanol p.a, detection with UV light $254 \mathrm{~nm}$ and $0.05 \mathrm{M}$ H2SO4 sprayer. Completeness identification was also carried out descriptive labeling of herbal products containing paracetamol.

Positive samples contain paracetamol if the $R f$ value and spot color are similar to the paracetamol comparison standard. The Rf results obtained that samples with codes $F, I, K$, and $L$ were $0.68 ; 0.68 ; 0.68$ and 0.68 which are the similar as the standard Rf for comparison of paracetamol and positive control which is 0.69. The conclusion of the research is that there are various brands of pegal linu herb sold in Indonesia that are suspected to contain 4 brands of paracetamol. Research suggestions for consumers who consume a brand of traditional herbal medicine are expected to be more selective in choosing herbal medicine by first checking the product registration number.
\end{abstract}

Keywords : Identification, Paracetamol, Herbal pain relief 


\section{PENDAHULUAN}

Obat tradisional yang sering dikonsumsi masyarakat Indonesia adalah jamu. Jumlah merk sediaan jamu di Indonesia adalah sebanyak lebih dari 8000 dan 50\% penduduk Indonesia telah menggunakan jamu dan 96\% diantaranya merasakan manfaatnya. Jenis jamu yang beredar di Indonesia sangat banyak contohnya seperti jamu pegal linu, jamu rematik, jamu asma, jamu batuk, dan lain sebagainya. Persentase penggunaan tumbuhan obat untuk jamu adalah jahe 50,36 \%, kencur $48,77 \%$, temulawak 39,65\%, meniran $13,93 \%$ dan mengkudu $11,17 \%$ (KEMENKES RI, 2019).

Jamu dengan khasiat pegal linu merupakan salah satu jenis produk jamu yang penggunaannya paling luas di masyarakat. Jenis sediaan jamu ini rawan untuk "dipalsukan" dengan penambahan senyawa kimia obat (BKO) ke dalam produk. Dari 114 merk jamu pegal linu yang diteliti, didapatkan 52 merk yang mengandung BKO dengan jenis BKO yang paling banyak terdeteksi adalah parasetamol (30,7\%), fenilbutazon (20, 4\%), piroksikam $(7,1 \%)$ dan asam mefenamat (3,5\%) (Gitawati, 2013). Penatalaksanaan pegal linu dapat melalui terapi non farmakologi dan farmakologi. Terapi non farmakologi dapat berupa olahraga, penggunaan vitamin, atau obat tradisional sedangkan terapi farmakologi melalui penggunaan obat kimia baik secara oral maupun topikal. Terapi farmakologi pegal linu untuk mengurangi keluhan nyeri melalui penggunaan jenis analgetika. Analgetika yang efektif untuk pegal linu melalui penggunaan per oral adalah parasetamol (asetaminofen) dan aspirin. Obat kimia jenis analgetik seperti parasetamol sering ditambahkan ke dalam produk obat tradisional seperti jamu (Saputra, 2015).

Minat masyarakat yang tinggi ini membuat beberapa produsen jamu mungkin saja menambahkan bahan kimia obat sesuai dengan khasiat obat tradisional yang di produksinya (Khoirunnisa et al., 2017). Permenkes No.006/Menkes/Per/V/2012 pasal 33 dan 37 tentang industri dan usaha obat tradisional menyatakan bahwa obat tradisional tidak boleh mengandung bahan kimia obat (BKO) (Peraturan Pemerintah (PP), 2012). Berbagai jenis sediaan jamu dapat ditemui di apotek, toko obat, dan depot jamu. Pada depot jamu perizinan tidak seketat pada 
apotek dan toko obat namun macam dan jenis bentuk sediaan jamu lebih beragam dapat ditemukan pada depot jamu. Diharapkan produk yang dijual pada depot jamu dapat dipastikan keamanannya untuk dikonsumsi. Pada aplikasi Google Maps (2021) ditemukan keberadaan depot jamu banyak ditemukan di Kota Denpasar dibandingkan kabupaten lain di Bali. Namun belum didapatkan tingkat konsumsi jamu di setiap kabupaten di Bali.

Nusa Bali (2020), memberitakan sidak jamu di Jembrana yang merupakan ibu kota di salah satu kabupaten di Bali ditemukan 14 toko dan warung/depot yang menjual jamu mengandung bahan kimia obat (BKO) yang dilarang Balai Pengawas Obat dan Makanan (BPOM), namun tidak disebutkan merk jamu yang

\section{METODE PENELITIAN} MATERIAL

Bahan-bahan yang digunakan yaitu methanol p.a, etanol p.a, parasetamol BPFI, $\mathrm{H}_{2} \mathrm{SO}_{4}$ 0,05 M, dan 14 sampel jamu pegal linu sediaan serbuk berbagai merek yaitu sampel jamu kode A, sampel jamu kode B, sampel jamu kode C, sampel jamu kode D, sampel jamu kode E, sampel jamu kode F, sampel mengandung BKO (NUSABALI, n.d.). Identifikasi dari 14 (empat belas) sampel jamu pegel linu yang beredar di Daerah Istimewa Yogyakarta dengan menggunakan metode kromatografi lapis tipis ditemukan 3 (tiga) sampel jamu mengandung parasetamol (Harimurti et al., 2020). Identifikasi senyawa dengan kromatografi lapis tipis (KLT) merupakan metode analisa kualitatif pilihan pertama jika ingin memisahkan suatu campuran obat atau ekstrak sebab KLT merupakan metode yang sederhana dan cepat. KLT digunakan secara luas untuk analisis obat (Wulandari, 2011). Tujuan penelitian ini adalah untuk mengetahui adanya tidaknya kandungan bahan kimia obat parasetamol pada jamu pegal linu yang dijual di depot jamu kota Denpasar.

jamu kode $G$, sampel jamu kode $H$, sampel jamu kode I, sampel jamu kode $\mathrm{J}$, sampel jamu kode $\mathrm{K}$, sampel jamu kode L, sampel $\mathrm{M}$, dan sampel jamu kode N. Alat yang digunakan yaitu plat KLT silika GF254, pipa kapiler, lemari asam, bejana kromatografi (chamber), oven, timbangan neraca analitik, alatalat gelas,kertas saring.

https://doi.org/10.33759/jrki.v4i1.208 


\section{Rancangan Penelitian}

Penelitian ini merupakan penelitian deskriptif eksploratif, untuk melakukan identifikasi terhadap ada tidaknya kandungan bahan kimia obat parasetamol pada sampel berbagai merk sediaan jamu pegal linu sediaan serbuk yang dilakukan di laboratorium kimia Universitas Bali Internasional pada bulan Juli 2021. Pengumpulan sampel dilakukan dengan membeli jamu yang sesuai dengan kriteria peneliti di beberapa depot jamu yang tersebar di Kota Denpasar.

\section{Prosedur Penelitian}

1. Preparasi sampel jamu pegal linu

Ditimbang satu dosis jamu 700 mg, dimasukan kedalam erlenmayer , ditambah $25 \mathrm{ml}$ etanol p.a, kocok selama 30 menit, disentrifuge, dipisahkan antara residu dan fitrat. Hal tersebut diulang sebanyak $3 \mathrm{x}$ untuk tiap jenis merk jamu. Filtrat yang didapatkan disaring kemudian diuapkan diatas tangas air pada suhu lebih kurang $70^{\circ} \mathrm{C}$ sampai kering, sisa penguapan dilarutkan dalam $10 \mathrm{ml}$ etanol p.a.

2. Pembuatan larutan kontrol positif

Ditimbang satu dosis jamu 700 mg, dimasukan ke dalam erlenmayer, Ditambah 10 mg bahan baku pembanding parasetamol BPFI kemudian ditambah $25 \mathrm{ml}$ etanol, Kocok selama 30 menit, disentrifuge, dipisahkan antara residu dan filtrate. Hal tersebut diulang sebanyak $3 x$ untuk tiap jenis merk jamu. Filtrat yang didapatkan disaring kemudian diuapkan diatas tangas air pada suhu lebih kurang $70^{\circ} \mathrm{C}$ sampai kering, sisa penguapan dilarutkan dalam $10 \mathrm{ml}$ etanol p.a.

3. Larutan Baku Parasetamol

Dibuat larutan baku parasetamol BPFI $0,1 \% \mathrm{~b} / \mathrm{v}$ atau $1000 \mathrm{ppm}$ sebanyak 10 $\mathrm{ml}$ dalam etanol p.a

4. Pemilihan fase gerak (eluen)

Dilakukan pemilihan fase gerak terbaik dari tiga jenis fase gerak yang dicobakan untuk pengembangan yaitu :

a. kloroform: methanol

(Saputra, 2015)

b. etil asetat : etanol : amonia (85:10:5) (Indriatmoko et al., 2019)

c. Etanol (Depkes RI, 1995)

Larutan uji yang digunakan yaitu baku pembanding dan kontrol positif ditotolkan pada plat KLT silika gel GF 254 dikembangkan dengan 3 (tiga) jenis fase gerak yang berbeda tersebut. Didapatkan hasil hanya fase gerak berupa etanol p.a yang 
menunjukkan adanya spot warna positif dan baku pembanding ditotolkan ungu pada kedua larutan uji.

5. Identifikasi dengan Kromatografi Lapis Tipis

Sebelum sampel ditotolkan pada plat KLT silika gel GF 254 ukuran 20×20 $\mathrm{cm}$ dicuci dengan methanol kemudian diaktivasi pada suhu $120^{\circ} \mathrm{C}$ selama 30 menit. Plat diberi garis dengan menggunakan pensil dengan jarak $2 \mathrm{~cm}$ dari tepi atas dan tepi bawah. Larutan uji berupa larutan sampel, kontrol pada plat KLT dengan skala $2 \mathrm{~cm}$ antar larutan uji dengan volume penotolan 15 $\mu$ l. Plat dimasukkan ke dalam chamber yang telah dijenuhkan dengan fase gerak terbaik untuk pengembangan. Setelah selesai pengembangan plat yang telah dikering udarakan, lalu dilakukan deteksi dengan menggunakan sinar UV $254 \mathrm{~nm}$ dan disemprot dengan $\mathrm{H}_{2} \mathrm{SO}_{4}$ encer. Hal ini diulang sebanyak 2 (dua) kali dan didapatkan hasil yang serupa.

\section{Analisa Data}

Jarak pengembangan senyawa pada kromatografi dinyatakan dengan angka Rf.

$$
\mathrm{RF}=\frac{\text { jarak titik pusat bercak dari titik awal }}{\text { jarak garis depan dari titik awal }}
$$

Berdasarkan harga Rf dan warna bercak noda yang dihasilkan dapat dinyatakan:

a. Apabila harga $\mathrm{Rf}$ larutan sampel mendekati larutan baku pembanding dan warna kedua bercak sama, maka sampel jamu pegal linu sediaan serbuk yang diteliti mengandung parasetamol (selisih harga Rf larutan uji

\section{HASIL DAN PEMBAHASAN}

Empat belas (14) sampel jamu pegal linu sediaan serbuk berbagai merk dengan larutan baku pembanding kurang dari sama dengan 0,05).

b. Sedangkan bila harga Rf larutan uji tidak mendekati harga Rf larutan pembanding dan kedua warna bercak tidak sama maka sampel jamu pegal linu sediaan serbuk yang diteliti tidak mengandung parasetamol

yang dideskripsikan dengan kode merk jamu diperoleh dari depot-depot jamu yang tersebar di berbagai wilayah Kota 
Denpasar. Dilakukan pengamatan label kemasan jamu yang meliputi nama produsen, komposisi, expired date
(ED), khasiat, nomor ijin edar (NIE), dan nomor batch sesuai tabel I.

Tabel I. Pengamatan Label Kemasan Sampel Penelitian

\begin{tabular}{lcccccc}
\hline $\begin{array}{c}\text { Kode Merk } \\
\text { Jamu }\end{array}$ & Produsen & Komposisi & ED & Khasiat & NIE & $\begin{array}{c}\text { Nomor } \\
\text { Batch }\end{array}$ \\
\hline A & Ada & Ada & Ada & Ada & Ada & Ada \\
\hline B & Ada & Ada & Ada & Ada & Ada & Ada \\
\hline C & Ada & Ada & Ada & Ada & Ada & Ada \\
\hline $\mathbf{D}$ & Ada & Ada & Ada & Ada & Ada & Ada \\
\hline $\mathbf{E}$ & Ada & Ada & Ada & Ada & Ada & Ada \\
\hline $\mathbf{F}$ & Ada & Ada & Ada & Ada & Ada & Ada \\
\hline G & Ada & Ada & Ada & Ada & Ada & Ada \\
\hline $\mathbf{H}$ & Ada & Ada & Ada & Ada & Ada & Ada \\
\hline $\mathbf{I}$ & Ada & Ada & Ada & Ada & Ada & Ada \\
\hline J & Ada & Ada & Ada & Ada & Ada & Ada \\
\hline $\mathbf{L}$ & Ada & Ada & Ada & Ada & Ada & Ada \\
\hline $\mathbf{M}$ & Ada & Ada & Ada & Ada & Ada & Ada \\
\hline $\mathbf{N}$ & Ada & Ada & Ada & Ada & Ada & Ada \\
\hline & Ada & Ada & Ada & Ada & Ada & Ada \\
\hline
\end{tabular}

Sampel jamu tersebut kemudian dilakukan pemeriksaan cek produk melalui website BPOM RI yaitu cekbpom.pom.go.id dengan memasukan nomor registrasi (nomor ijin edar) yang tertera pada kemasan produk. Didapatkan dari 14 sampel jamu terdapat sebanyak 7 sampel yang mencantumkan nomor ijin edar fiktif atau NIE fiktif. Tujuh sampel merk jamu yang tidak teregistrasi dan tidak memiliki izin edar dari BPOM seperti yan tertera pada tabel II di bagian keterangan. Sampel jamu tersebut kemungkinan merupakan jamu racikan rumah tangga. Danang dkk, 2019 menyatakan jamu yang tidak teregistrasi dan tidak memiliki izin karena tidak diuji untuk syarat-syarat kualitas jamu oleh BPOM sebelum dijual di pasaran sehingga kemungkinan besar mengandung BKO. 
Tabel II. Deskripsi Sampel Penelitian

\begin{tabular}{|c|c|c|c|c|}
\hline $\begin{array}{l}\text { Merk } \\
\text { Jamu }\end{array}$ & Komposisi & Khasiat dan Kegunaan & Dosis & Keterangan \\
\hline A & $\begin{array}{l}\text { Ficus stipulosa } 20 \% \text {, vitex } \\
\text { canabifolia } 20 \% \text {, piper } \\
\text { betle } 10 \% \text {, dan bahan-bahan } \\
\text { lain } 100 \% \text {. }\end{array}$ & $\begin{array}{l}\text { Mengobati nyeri pada } \\
\text { tulang, sakit encok, sakit } \\
\text { pinggang, persendian } \\
\text { terasa sakit nyeri dan } \\
\text { linu, flue pada tulang, } \\
\text { mengobati keseleo atau } \\
\text { terkilir, menghangatkan } \\
\text { badan dan mencegah } \\
\text { masuk angin. }\end{array}$ & $\begin{array}{l}\text { Sehari } 1 \\
\text { bungkus } \\
\text { kalua perlu } \\
2 \text { bungkus } \\
\text { diminum } \\
\text { pagi \& } \\
\text { malam hari } \\
\text { secara } \\
\text { teratur. }\end{array}$ & $\begin{array}{l}\text { Tidak } \\
\text { Teregistrasi } \\
\text { BPOM }\end{array}$ \\
\hline B & $\begin{array}{l}\text { Panax Ginseng Radix, } \\
\text { Zingiberis Aromaticae } \\
\text { Rhizoma, Languatis } \\
\text { Galanga Rhizoma } \\
\text { (Lengkuas), Piper } \\
\text { Retrofractum Fructus, dan } \\
\text { Cyperi Rhizoma (Rumput } \\
\text { Teki). }\end{array}$ & $\begin{array}{l}\text { Jamu yang berkhasiat } \\
\text { menghilangkan rasa } \\
\text { lelah, pegal linu, nyeri } \\
\text { pada otot dan tulang } \\
\text { diseluruh tubuh setelah } \\
\text { bekerja, berolahraga atau } \\
\text { melakukan perjalanan } \\
\text { jauh, menyehatkan dan } \\
\text { menyegarkan badan. }\end{array}$ & $\begin{array}{l}2 \text { x sehari } \\
\text { @ } 1 \\
\text { bungkus } \\
\text { selama } \\
\text { diperlukan. }\end{array}$ & $\begin{array}{l}\text { Teregistrasi } \\
\text { BPOM }\end{array}$ \\
\hline $\mathrm{C}$ & $\begin{array}{l}\text { Ekstrak Paeonia rubrae, } \\
\text { Platicodi Radix, } \\
\text { Glycyrrhizae Radix (akar } \\
\text { manis), Disploclisia } \\
\text { glucoscens diel, Menthae } \\
\text { piperitae (peppermint), } \\
\text { Curcuma Rhizoma } \\
\text { (temulawak), dan Centella } \\
\text { Herba (pegagan). }\end{array}$ & $\begin{array}{l}\text { Secara tradisional } \\
\text { digunakan untuk } \\
\text { membantu memperbaiki } \\
\text { sirkulasi darah, } \\
\text { membantu mengatasi } \\
\text { masuk angin, membantu } \\
\text { mengatasi pegal linu dan } \\
\text { encok, serta dapat } \\
\text { digunakan untuk } \\
\text { membantu mengatasi } \\
\text { memar, bengkak, } \\
\text { keseleo, dan terkilir. }\end{array}$ & $\begin{array}{l}1 \text { sachet, } \\
\text { diminum } 3 \\
\text { kali sehari. }\end{array}$ & $\begin{array}{l}\text { Teregistrasi } \\
\text { BPOM }\end{array}$ \\
\hline $\mathrm{D}$ & $\begin{array}{l}\text { Equisetum debile Herba } \\
\text { (Greges Otot), Alyxiae } \\
\text { stellatae Cortex, } \\
\text { Coriandrum sativum } \\
\text { Fructus, Piperis nigri } \\
\text { Fructus, Plantaginis majoris } \\
\text { Folium, Zingiberis } \\
\text { officinalis Rhizoma, Panax } \\
\text { ginseng Radix (Ginseng), } \\
\text { Curcumae domesticae } \\
\text { Rhizoma, dan Kaempferiae }\end{array}$ & $\begin{array}{l}\text { Membantu meredakan } \\
\text { nyeri pada persendian, } \\
\text { pegal-pegal, linu dan } \\
\text { encok. Juga } \\
\text { untukmemelihara } \\
\text { kesehatan dan membantu } \\
\text { memperbaiki peredaran } \\
\text { darah. }\end{array}$ & $\begin{array}{l}\text { Satu hari } 2 \\
\text { bungkus, } \\
\text { pagi dan } \\
\text { sore hari } \\
\text { selama } \\
\text { diperlukan. }\end{array}$ & $\begin{array}{l}\text { Teregistrasi } \\
\text { BPOM }\end{array}$ \\
\hline
\end{tabular}


galangae Rhizoma.

\begin{tabular}{|c|c|c|c|c|}
\hline $\mathrm{E}$ & $\begin{array}{l}\text { Zingiberis officinalis } \\
\text { Rhizoma } 0.42 \mathrm{~g}, \text { Feoniculi } \\
\text { vulgaris Fructus } 0.21 \mathrm{~g} \text {, } \\
\text { Euchrestae horsfieldii } \\
\text { Semen } 0.42 \mathrm{~g} \text {, Eurycomae } \\
\text { longifoliae Radix } 0.35 \mathrm{~g}, \\
\text { Curcumae xanthorrhizae } \\
\text { Rhizoma } 2.00 \mathrm{~g}, \\
\text { Kaempferiae galangae } \\
\text { Rhizoma } 1.50 \mathrm{~g} \text {, Alpinia } \\
\text { galangae Rhizoma } 0.80 \mathrm{~g}, \\
\text { Piperis retrofracti Fructus } \\
0.80 \mathrm{~g}, \text { Piperis nigri Fructus } \\
0,50 \mathrm{~g} \text {. }\end{array}$ & $\begin{array}{l}\text { Membantu meredakan } \\
\text { pegal linu dan } \\
\text { menyegarkan badan. }\end{array}$ & $2 x$ sehari & $\begin{array}{l}\text { Teregistrasi } \\
\text { BPOM }\end{array}$ \\
\hline $\mathrm{F}$ & $\begin{array}{l}\text { Zingiberis Rhizoma 25\%, } \\
\text { Tinosporae Krispa } 20 \% \\
\text { Piper Nigrum 15\%, Panax } \\
\text { Ginseng } 10 \% \text { Royal Jelly } \\
5 \% \text {, Bahan-bahan lain } \\
\text { sampai } 100 \% \text {. }\end{array}$ & $\begin{array}{l}\text { Menyembuhkan asam } \\
\text { urat, nyeri tulang, pegal } \\
\text { linu, encok, rheumatic, } \\
\text { darah tinggi, sakit nyeri } \\
\text { otot, dan sering } \\
\text { kesemutan. }\end{array}$ & $\begin{array}{l}\text { 2x 1 pagi } \\
\text { dan sore } \\
\text { secara } \\
\text { teratur } \\
\text { sesudah } \\
\text { makan } \\
\end{array}$ & $\begin{array}{l}\text { Tidak } \\
\text { teregistrasi } \\
\text { BPOM }\end{array}$ \\
\hline G & $\begin{array}{l}\text { Zingiberis officinalis } \\
\text { Rhizoma, Kaempferiae } \\
\text { galangae Rhizoma, } \\
\text { Myristicae fragransis } \\
\text { Semen, Alpinia galangae } \\
\text { Rhizoma, Piperis retrofracti } \\
\text { Fructus, Zingiberis } \\
\text { zerumbeti Rhizoma, } \\
\text { Equiseti debilis Herba, } \\
\text { Melaleucae Leucadendron } \\
\text { fructus, Piperis nigri } \\
\text { Fructus, dan Melaleucae } \\
\text { leucadendron Folium. }\end{array}$ & $\begin{array}{l}\text { Membantu meredakan } \\
\text { pegal-pegal dan linu, } \\
\text { membantu memelihara } \\
\text { stamina. }\end{array}$ & $\begin{array}{l}\text { Seminggu } \\
\text { duakali@ } \\
\text { satu } \\
\text { bungkus. }\end{array}$ & $\begin{array}{l}\text { Teregistrasi } \\
\text { BPOM }\end{array}$ \\
\hline $\mathrm{H}$ & $\begin{array}{l}\text { Piper Nigrum, Kaem feriag } \\
\text { Rhizoma, Zingiberis } \\
\text { Aromatiae, dan Bahan- } \\
\text { bahan lain. }\end{array}$ & $\begin{array}{l}\text { Mengobati asam urat, } \\
\text { kolesterol, pegal linu, } \\
\text { rheumatic. }\end{array}$ & $\begin{array}{l}\text { Sehari satu } \\
\text { bungkus } \\
\text { kalau } \\
\text { diperlukan } \\
2 \text { bungkus } \\
\text { pagi-sore. }\end{array}$ & $\begin{array}{l}\text { Tidak } \\
\text { Teregistrasi } \\
\text { BPOM }\end{array}$ \\
\hline I & $\begin{array}{l}\text { Centella Asiatica } 35 \% \text {, } \\
\text { Glaziosa Superbal 25\%, } \\
\text { Minosa Pudical } 15 \%, \\
\text { Phyllantnus Urinalialinn } \\
\text { 10\%, Sonchus Arvesisi } \\
\text { 10\%, dan lain-lain sampai }\end{array}$ & $\begin{array}{l}\text { Asam urat, stress, } \\
\text { rheumatic menahun, kaki } \\
\text { bengkak-bengkak, } \\
\text { menurunkan kolesterol, } \\
\text { otot terasa kaku, demam, } \\
\text { bronchitis, meriang, }\end{array}$ & $\begin{array}{l}1 \text { kali } \\
\text { sehari }\end{array}$ & $\begin{array}{l}\text { Tidak } \\
\text { Teregistrasi } \\
\text { BPOM }\end{array}$ \\
\hline
\end{tabular}




\begin{tabular}{|c|c|c|c|c|}
\hline & $100 \%$ & $\begin{array}{l}\text { menstabilkan hormone } \\
\text { tubuh, menghancurkan } \\
\text { bekuan darah, menjaga } \\
\text { stamina sehingga } \\
\text { membuat orang Panjang } \\
\text { umur. }\end{array}$ & & \\
\hline $\mathrm{J}$ & $\begin{array}{l}\text { Royal Jelly, Foeniculli } \\
\text { Fructus, Lisqustici Radic, } \\
\text { Conidia Radic, dan bahan- } \\
\text { bahan lain. }\end{array}$ & $\begin{array}{l}\text { Untuk mengobati asam } \\
\text { urat,menurunkan } \\
\text { kolesterol, pegal linu, } \\
\text { keputihan, mengurangi } \\
\text { rasa sakit pada dilep } \\
\text { untuk ibu habis bersalin, } \\
\text { melancarkan peredaran } \\
\text { darah, menambahkan } \\
\text { kebugaran olah raga dan } \\
\text { mengobati kencing } \\
\text { manis. }\end{array}$ & $\begin{array}{l}\text { Sehari } 1 \\
\text { bungkus } \\
\text { diminum } \\
\text { pagi dan } \\
\text { malam hari } \\
\text { sebelum } \\
\text { tidur secara } \\
\text { teratur. }\end{array}$ & $\begin{array}{l}\text { Tidak } \\
\text { Teregistrasi } \\
\text { BPOM }\end{array}$ \\
\hline K & $\begin{array}{l}\text { Piper Ningrum } 30 \% \text {, } \\
\text { Ekstrak Ginseng } 30 \% \text {, } \\
\text { Zingiberis Rhinoma } 30 \% \text {, } \\
\text { dan bahan-bahan lain } 10 \% \text {. }\end{array}$ & $\begin{array}{l}\text { Mengobati berbagai } \\
\text { macam penyakit seperti } \\
\text { diantaranya asam urat, } \\
\text { cikungunya, sakit } \\
\text { pinggang, pegal linu, } \\
\text { nyeri otot dan encok, } \\
\text { rheumatik. }\end{array}$ & $\begin{array}{l}1 \times 2 \\
\text { sesudah } \\
\text { makan, bila } \\
\text { sakitnya } \\
\text { parah } \\
\text { minum } 2 \times \\
2 \text { dalam } \\
\text { sehari. }\end{array}$ & $\begin{array}{l}\text { Tidak } \\
\text { Teregistrasi } \\
\text { BPOM }\end{array}$ \\
\hline $\mathrm{L}$ & $\begin{array}{l}\text { Centella Asiatica } 35 \% \text {, } \\
\text { Glaziosa Superbal 25\%, } \\
\text { Phyllanthus Urinalianinn } \\
\text { 20\%, Minosa Pudical 10\% } \\
\text { dan bahan lain sampai } 100 \\
\% \text {. }\end{array}$ & $\begin{array}{l}\text { Menyembuhkan asam } \\
\text { urat, pegal linu, } \\
\text { rhematik, nyeri otot, } \\
\text { sakit sendi, sakit } \\
\text { pinggang, demam, } \\
\text { meriang, sakit gigi, } \\
\text { menurunkan kolesterol. }\end{array}$ & 2 x sehari. & $\begin{array}{l}\text { Tidak } \\
\text { Teregistrasi } \\
\text { BPOM }\end{array}$ \\
\hline M & $\begin{array}{l}\text { Sonchi Folium } 700 \mathrm{mg} \text {, } \\
\text { Curcumae Rhizoma } 1050 \\
\text { mg, Orthosiphonis Folium } \\
560 \mathrm{mg} \text {, Andrographidis } \\
\text { Herba } 210 \mathrm{mg} \text {, Paperis non } \\
\text { Fructus } 350 \mathrm{mg} \text {, Syaigi } \\
\text { aromatice Folium } 1175 \mathrm{mg} \text {, } \\
\text { Betrofracti Fructus } 490 \mathrm{mg}, \\
\text { dan Burmani Certurung. }\end{array}$ & $\begin{array}{l}\text { Membantu meredakan } \\
\text { nyeri pada persendian, } \\
\text { pegal linu, dan nyeri } \\
\text { akibat encok. }\end{array}$ & $\begin{array}{l}2 \times \text { sehari } 1 \\
\text { bungkus } \\
\text { pagi dan } \\
\text { sore. }\end{array}$ & $\begin{array}{l}\text { Teregistrasi } \\
\text { BPOM }\end{array}$ \\
\hline $\mathrm{N}$ & $\begin{array}{l}\text { Piperis retrofracti Fructus } \\
0,56 \mathrm{~g} \text {, Eucalyptus globulus } \\
\text { Fructus } 0,84 \mathrm{~g}, \text { Zingiberis }\end{array}$ & $\begin{array}{l}\text { Membantu meredakan } \\
\text { pegal linu dan sakit otot } \\
\text { pinggang. }\end{array}$ & $\begin{array}{l}2 \times 1 \\
\text { bungkus } \\
\text { sehari pagi }\end{array}$ & $\begin{array}{l}\text { Teregistrasi } \\
\text { BPOM }\end{array}$ \\
\hline
\end{tabular}


aromaticae Rhizoma 0,84 g.

Zingiberis officinale

Rhizoma 0,84 9. Curcumae

xanthorrhizae Rhizoma

0,56g. dan bahan - bahan

lain hingga 7 gram terdiri

dari: Foeniculum vulgare

Fructus, Alyxiae reinwardtii

Cortex, Languas galanga

Rhizoma, Smilax glabra

Rhizoma, Parkiae

roxburghii Semen,

Orthosiphon aristatus

Folium, Carum copticum

Fructus, Piperis nigri

Fructus, Phyllanthus niruri

Herba, Cinamomum

burmanii Cortex.

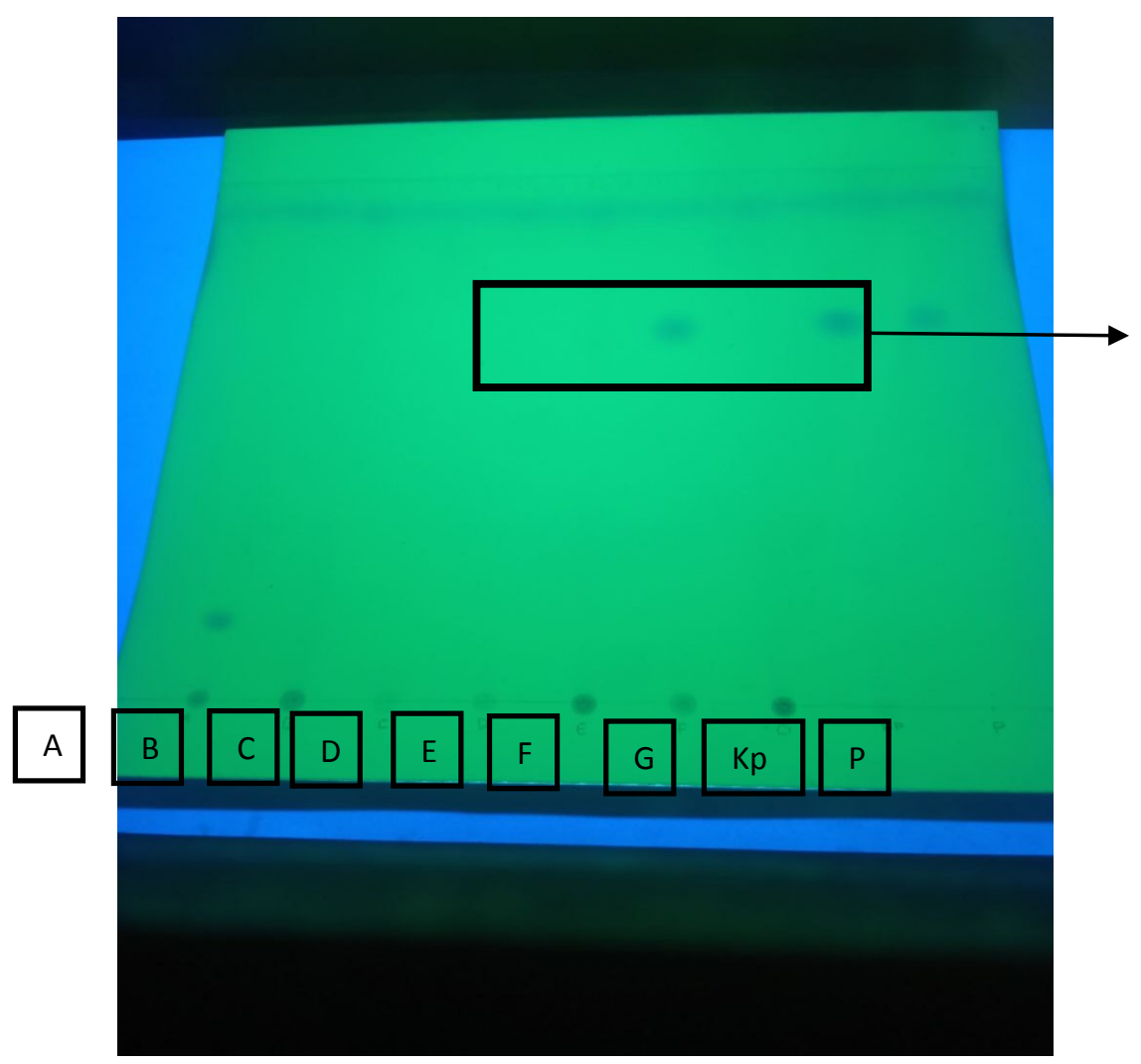

Gambar I. Kromatogram Parasetamol pada Plat KLT GF 254 Pertama 

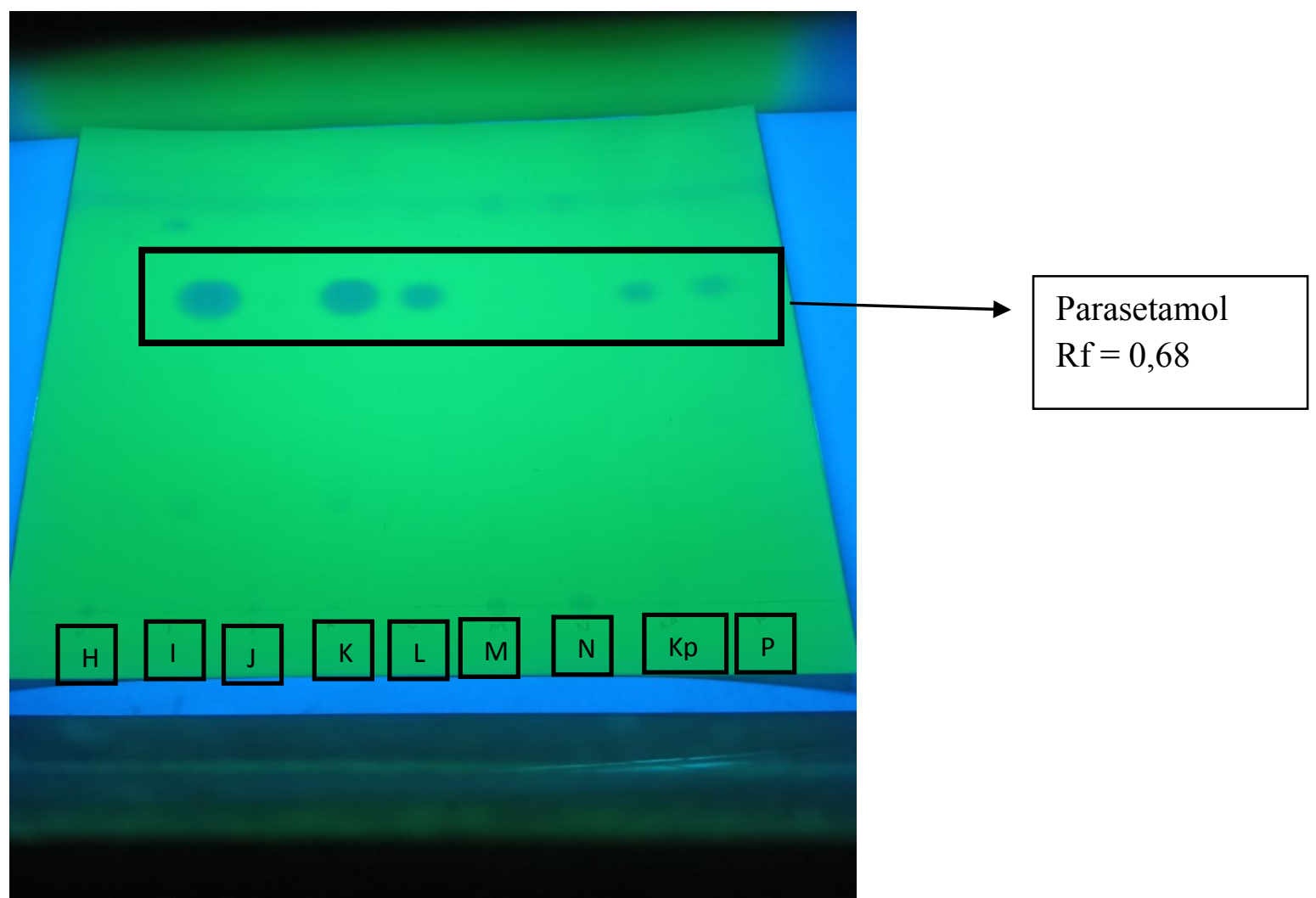

Gambar II. Kromatogram Parasetamol pada Plat KLT GF254 Kedua

Keterangan:

P : : Baku Pembanding Parasetamol

Kp : Sampel + Baku pembanding (kontrol positif)

A, B,C,D,R,F,G,H,I,J,K,L,M,N : kode merk jamu pegal linu

Tabel III Hasil Deteksi Plat KLT Pada Sinar UV 254 nm

\begin{tabular}{lccccc}
\hline Baku dan Sampel & $\begin{array}{c}\text { Warna } \\
\text { Bercak }\end{array}$ & $\begin{array}{c}\text { Tinggi } \\
\text { bercak } \\
(\mathbf{c m})\end{array}$ & $\begin{array}{c}\text { Jarak } \\
\text { Rambat } \\
(\mathbf{c m})\end{array}$ & $\begin{array}{c}\text { Nilai } \\
\text { Rf }\end{array}$ & Kesimpulan \\
\hline Baku Parasetamol & Ungu & 11,04 & 16 & 0,69 & Positif \\
Kontrol Positif & Ungu & 11,04 & 16 & 0,69 & Positif \\
A & Ungu & 2,08 & 16 & 0,13 & Negatif \\
B & - & & 16 & - & Negatif \\
C & - & & 16 & - & Negatif \\
D & - & & 16 & - & Negatif \\
E & - & & 16 & - & Negatif \\
F & Ungu & 10,88 & 16 & 0,68 & Positif \\
G & - & & 16 & - & Negatif \\
H & - & & 16 & - & Negatif \\
I & Ungu & 10,88 & 16 & 0,68 & Positif \\
J & - & & 16 & - & Negatif \\
K & Ungu & 10,88 & 16 & 0,68 & Positif \\
L & Ungu & 10,88 & 16 & 0,68 & Positif
\end{tabular}




\begin{tabular}{lllll}
$\mathbf{M}$ & - & 16 & - & Negatif \\
$\mathbf{N}$ & - & 16 & - & Negatif \\
\hline
\end{tabular}

Sebelum lempeng plat KLT digunakan, lempeng diaktivasi terlebih dahulu yang bertujuan untuk menghilangkan kelembaban air atmosfer yang teradsorbsi dalam lempeng (Wulandari, 2011). Fase gerak pada identifikasi parasetamol menggunakan fase gerak etanol. Pelarut organik yang digunakan sebagai fase gerak didasarkan kelarutan senyawa yang tertera pada monografi Farmakope Indonesia dan kutipan dari beberapa artikel jurnal. Pada pase gerak kloroform dan methanol, parasetamol tidak dapat terpartisi pada fase diam KLT.

Parameter pembanding antara senyawa baku dengan sampel penelitian adalah melalui nilai $\mathrm{Rf}$ dengan warna bercak noda yang muncul pada plat KLT telah dielusi dengan fase gerak. Dua senyawa atau lebih dapat dikatakan identik apabila mempunyai nilai $\mathrm{Rf}$ yang sama pada kondisi KLT yang sama dan selisih harga Rf larutan sampel uji dengan larutan baku pembanding kurang dari atau sama dengan dengan $0,05 \mathrm{~cm}$. Nilai $\mathrm{Rf}$ berjarak antara 0,00 sampai 1,00 (Gandjar dan Rohman, 2012).

Hasil identifikasi parasetamol setelah dideteksi dibawah sinar UV $254 \mathrm{~nm}$ dan reaksi semprot $\mathrm{H}_{2} \mathrm{SO}_{4}$ tidak menunjukan perbedaan nilai Rf. Pada kondisi identifikasi KLT parasetamol, didapatkan nilai $\mathrm{Rf}$ larutan baku pembanding parasetamol yaitu 0,69 dengan larutan kontrol positifnya yaitu 0,69 . Pembuatan larutan kontrol positif melalui penggunaan salah satu sampel jamu yang ditambah baku pembanding parasetamol bertujuan untuk memantapkan dan lebih meyakinkan dalam pengambilan keputusan identifikasi senyawa. Sehingga pada saat pengerjaan sampel peneliti akan memudahkan untuk mengambil keputusan apabila nilai $\mathrm{Rf}$ antara sampel, baku pembanding, dan kontrol positif sama.

Hasil identifikasi didapatkan nilai Rf untuk sampel F, I, K, dan L adalah sebesar 0,$68 ; 0,68 ; 0,68$ dan 0,68. Keempat nilai $\mathrm{Rf}$ tersebut mirip dengan nilai $\mathrm{Rf}$ baku pembanding parasetamol dan https://doi.org/10.33759/jrki.v4i1.208 
kontrol positif yaitu 0,69. Berdasarkan hasil tersebut dapat dinyatakan bahwa dari 14 jamu yang diidentifikasi, didapatkan 4 merk jamu yang diduga positif mengandung parasetamol sebab nilai Rf dan warna spot mirip dengan larutan baku pembanding dan kontrol positif yaitu berwarna ungu.

\section{KESIMPULAN}

Kesimpulan dari penelitian ini adalah:

1. Jamu pegal linu sediaan serbuk berbagai merk yang dijual di depot jamu di kota Denpasar diduga mengandung bahan kimia obat parasetamol sebanyak 4 merk dan merk jamu tersebut tidak teregistrasi BPOM.

2. Terdapat 7 sampel jamu yang mencantumkan nomor ijin edar fiktif atau tidak teregistrasi BPOM.

\section{UCAPAN TERIMAKASIH}

Pada kesempatan ini, peneliti ingin mengucapkan terima kasih kepada LP2M Universitas Bali Internasional yang telah membantu terwujudnya penelitian

\section{DAFTAR PUSTAKA}

Depkes RI. (1995). Farmakope

Indonesia edisi IV. In Departemen

Kesehatan Republik Indonesia.
Gandjar, I.G., dan Rohman, A., 2012. Analisis Obat Secara Spektrofotometri dan Kromatografi. Yogyakarta: Pustaka Pelajar

Gitawati, R. (2013). Analysis of Adulterated Jamu Pegal Linu Obtained from the Market in Jakarta. Buletin Penelitian Sistem Kesehatan, 16(3), 269-274. https://media.neliti.com/media/pub lications/20855-EN-analisisadulterasi-jamu-pegal-linu-yangdiperoleh-dari-pasar-di-jakartadan-sek.pdf

Harimurti, S., Ulandari, S., Widada, H., \& Damarwati, L. (2020).

Identifikasi Parasetamol dan Asam Mefenamat pada Jamu Pegel Linu dan Asam Urat yang Beredar di Daerah Istimewa Yogyakarta. 179-188. https://doi.org/10.20961/jpscr.v5i2. 41929

Indriatmoko, D., Rudiana, T., \& Saefullah, A. (2019). Analisis Kandungan Parasetamol pada Jamu Pegal Linu yang diperoleh dari Kawasan Industri Kecamatan Kibin Kabupaten Serang. Journal 
Itekimia, 5(1), 33-47.

KEMENKES RI. (2019).

Perkembangan Obat Tradisional di

Indonesia. Direktorat Produksi

Dan Distribusi Kefarmasian.

Khoirunnisa, S. M., Ulfa, A. M.,

Novika, M., Farmasi, P. S., \&

Malahayati, U. (2017). Identifikasi

Deksametason Dalam Jamu Pegal

Linu Sediaan Serbuk Yang Beredar

Di Pasar-Pasar Kota Bandar

Lampung. Journal of Science and

Applicative Technology, I(2), 94

101.

NUSABALI. (n.d.).

Peraturan Pemerintah (PP). (2012).

PERATURAN MENTERI

KESEHATAN REPUBLIK

INDONESIA NOMOR 006

TAHUN 2012 TENTANG

INDUSTRI DAN USAHA OBAT

TRADISIONAL Saputra, S. (2015). Identifikasi Bahan Kimia Obat dalam Jamu Pegel Linu Seduh dan Kemasan yang Dijual di Pasar Bandar. Jurnal Wiyata, 2(2), 188-192.

Wulandari, L. (2011). Kromatografi Lapis Tipis. In Taman Kampus Presindo. 